RE P O R T S

Estonian Journal of Archaeology, 2006, 10, 1, 81-88

Valter Lang, Aivar Kriiska and Arvi Haak

\title{
A NEW EARLY BRONZE AGE SOCKETED AXE
}

\author{
A bronze axe found from Eesnurga village is described. According to some indirect \\ parallels reported from Scandinavia and southern Baltic region, the axe can probably be \\ dated to period III of the Nordic Bronze Age. \\ On käsitletud Eesnurga külast leitud pronkskirvest. Otsustades mõningate ligikaudsete \\ paralleelide põhjal Skandinaaviast ja lõunapoolsest Baltikumist, on tegu arvatavasti pronksiaja \\ III perioodil valmistatud esemega. \\ Valter Lang, Chair of Archaeology, Department of History, University of Tartu, 3 Lossi St., \\ 51003 Tartu, Estonia; valter.lang@ut.ee \\ Aivar Kriiska, Chair of Archaeology, Department of History, University of Tartu, 3 Lossi St., \\ 51003 Tartu, Estonia; aivar.kriiska@ut.ee \\ Arvi Haak, Museum of Viljandi, 10 Laidoneri Square, 71020 Viljandi, Estonia; \\ arvi.haak@muuseum.viljandimaa.ee
}

As it recently became evident, there is a socketed bronze axe stored in the Museum of Viljandi, which had so far attracted no specific archaeological interest. The axe was discovered by Heino Mölter during field cultivation on the land of Lääne farm in the village of Eesnurga, located $1.5 \mathrm{~km}$ south of Kolga-Jaani (central southern Estonia) already in 1972 (Fig. 1). However, it was only in 1996 when the artefact was given to the Museum of Viljandi, and still ten years later when it finally attracted the attention of an archaeologist.

Lääne farm was located on a drumlin of northwest-southeast direction. The length of the drumlin is ca $1 \mathrm{~km}$ and its width is some hundred metres, with relative height until $48 \mathrm{~m}$ above sea level (in the Baltic system). The drumlin is situated in the central part of the Kolga-Jaani group of drumlins, where numerous sites and stray finds dating to various periods of the Stone Age and Bronze Age have been registered. Stone Age artefacts have also been reported from the land of Lääne farm (Anni 1921, 14). 


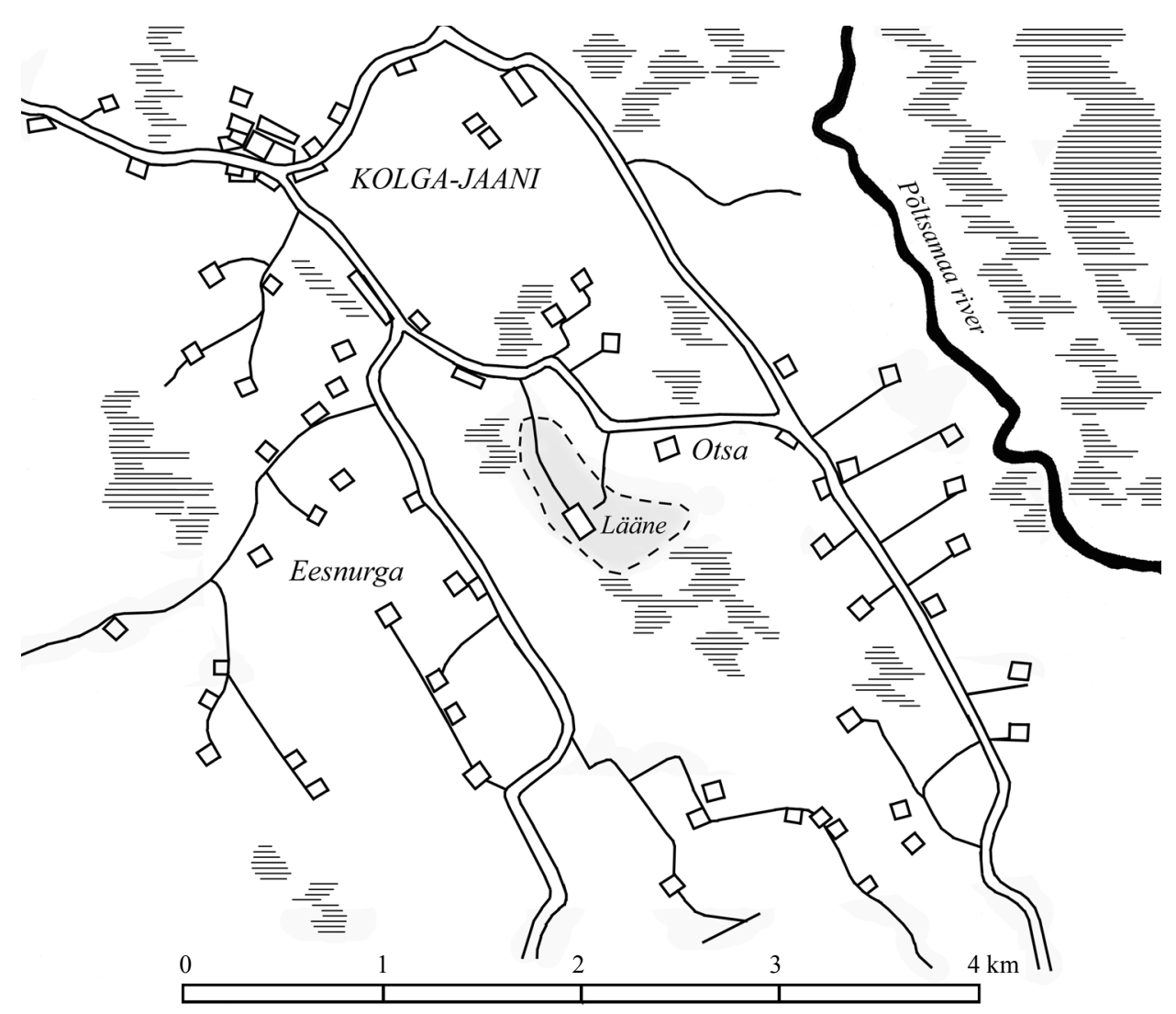

Fig. 1. Location of find of the Eesnurga axe.

Joon 1. Eesnurga pronkskirve leiukoht.

In April 2006, Aivar Kriiska, Arvi Haak and Andres Vindi visited the find spot. The whole drumlin had been turned into a cultivated field. A few flakes of local flint, and a small number of potsherds were collected during field-walking. However, the finds were rather scarce and cannot be connected with any clearcut prehistoric site.

The Eesnurga axe (Fig. 2) is relatively long and slender; its length is $142 \mathrm{~mm}$ and the width in the middle $24 \mathrm{~mm}$. The maximum width of the blade reaches $43 \mathrm{~mm}$, whereas the edge of the blade is slightly curved. The outer diameter of the socket's round-shaped mouth is $34 \mathrm{~mm}$ and the inner one $-25 \mathrm{~mm}$. The depth of the socket reaches $91 \mathrm{~mm}$. The axe is relatively evenly thickening towards the mouth of the socket and ends with a sausage-like undecorated bulge immediately beneath the mouth. The axe is furnished with an oval-shaped loop. The only decoration of the axe consists of symmetrically curved narrow bulges running parallel to the sharp edges of the wider sides and joining arc-wise on the narrow sides. The weight of the axe is $285.7 \mathrm{~g}$. 


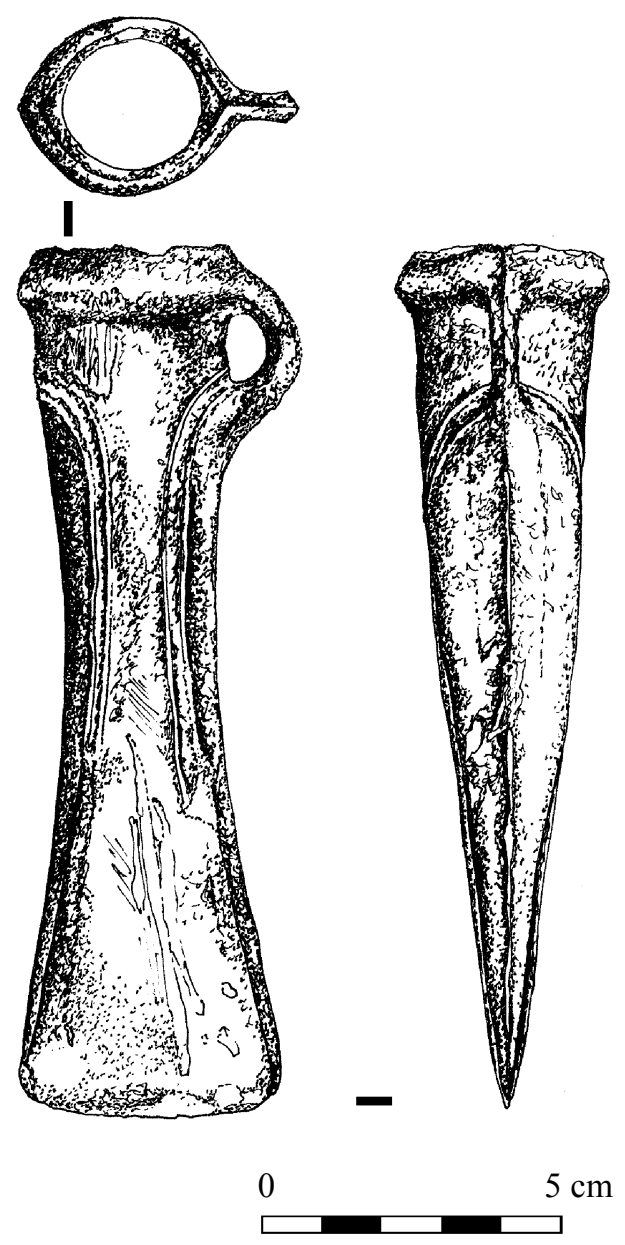

Fig. 2. Bronze axe from Eesnurga.

Joon 2. Eesnurga pronkskirves.

The dating and cultural determination of the axe under question is slightly complicated. From the first sight, it resembles the axes of the so-called Littausdorf type determined by Eduard Sturms (1936, 53 f, pl. 13: d) on the basis of a hoard in the previous East Prussia. Similar axes, which however have sturdier and smaller bodies, had been also reported from eastern Germany and Poland and dated according to co-finds from the IV period of the Scandinavian Bronze Age (1100900 BC). Therefore Šturms did not exclude the possibility that the Littausdorf axes might belong already to the late III period (1300-1100 BC); according to him, such axes could be located, both in typological and chronological terms, in between the long and slender socketed axes of period II (1500-1300 BC) and those of period IV (Šturms 1936, 54). One bronze axe, typologically close to the 
Littausdorf axes, has also been found in Põhjaka near Suure-Jaani (Fig. 3), not far from the axe of Eesnurga. The Põhjaka axe was published by Harri Moora (1938, 370, fig. 2) who supposed that it could even originate from a later time, i.e. period V of the Bronze Age (900-600 BC).

Some axes of the IV period, analogous to the Littausdorf type, have also been reported from Scandinavia: Gotland, Skåne and Denmark (Baudou 1960, 25). Further development of these axes was towards smaller dimensions, so that the length of the axes of period V or VI does not usually exceed 8-9 cm. On the other hand, there is also a rather similar group of socketed axes in Scandinavia, called group E by Andreas Oldeberg (1976, 9; 1974, figs. 470, 601, 1993, 2193, 2196b, 2218a), which on the basis of co-finds of at least some specimens seems to belong to the transition from period III to period IV. At least some axes of this group are decorated similarly with the Eesnurga axe.

However, all these axes are not the exact parallels to this new Estonian one. The main difference between the axe from Eesnurga and those mentioned above is that the former is remarkably longer, more slender and heavier than the latter. Judging by its general form and proportions, the Eesnurga axe resembles more the axes of periods II and III than those of periods IV or V. With this respect, one should mention a very unique socketed axe found from Järveküla, northern Estonia, which in morphological terms has many similarities with that of Eesnurga. The Järveküla axe can be considered the most beautiful artefact of the Estonian Bronze Age (Fig. 4), which still has no exact parallels. Generally, it should



Fig. 3. Bronze axe from Põhjaka (AI 3609).

Joon 3. Põhjaka pronkskirves. 


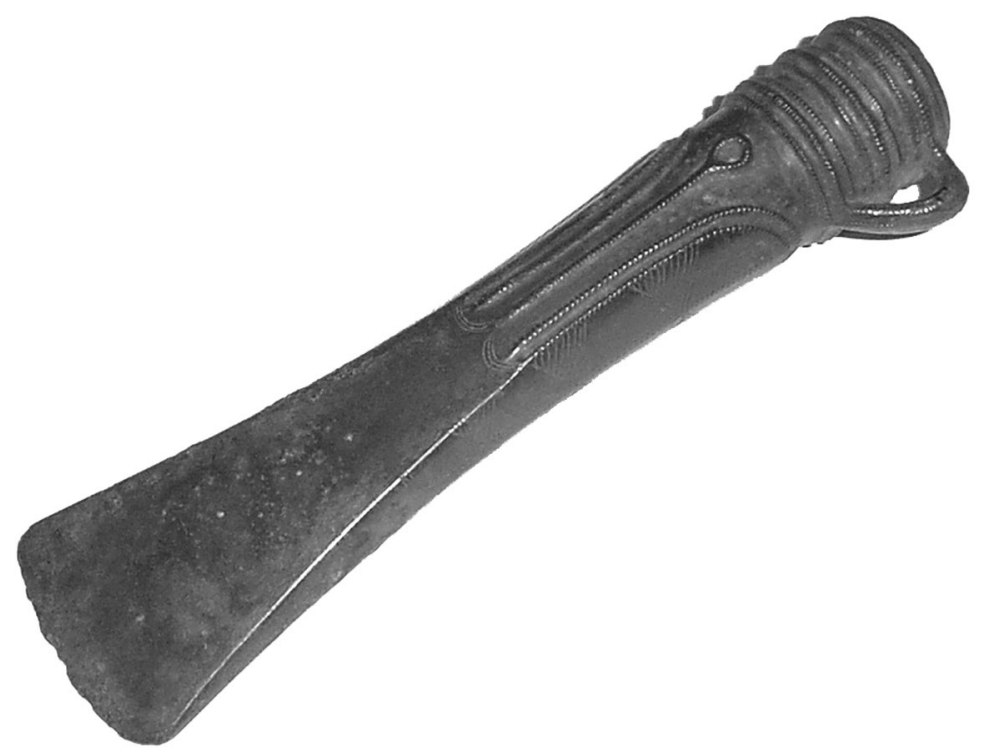

Fig. 4. Bronze axe from Järveküla (TLM 19855).

Joon 4. Järveküla pronkskirves.

belong to the group of so-called nordische Streitbeile by Ekkehard Aner (1962, $180 \mathrm{ff}$, figs. 6-8), and it also has indirect similarities with some specimens from Södermanland in Sweden (Montelius 1917/1991, fig. 878; Oldeberg 1976, fig. 2724). Judging by its general proportions, the shape of the blade and the decoration motifs, the Järveküla axe was presumably made somewhere in southern Scandinavia or northern Germany during period II. It is interesting to notice that similarly with the Eesnurga axe, the Järveküla axe is also decorated with additional bulges running parallel to the sharp edges of the wider sides and joining arc-wise on the narrow sides.

For conclusion it should be mentioned that judging by the general proportions, shape, dimensions and decoration, the Eesnurga axe should originate from the intermediate centuries between periods II and IV, i.e. most likely from period III of the Scandinavian Bronze Age. Where it was made is also difficult to establish; yet southern Scandinavia seems the most plausible area in this respect.

Thus, the axe of Eesnurga increased the number of metal artefacts of the Early Bronze Age (1800-1100 BC) in Estonia by one. Until recently, there was a total of 13 bronze artefacts dated to that era: eleven axes, one sickle and one spearhead (Fig. 5). In addition, there was data of two more flanged axes reported from the island of Muhu and from Valgjärve, southern Estonia, although they have not reached the museums. Thus, one can consider altogether 16 metal artefacts of the 




Fig. 5. Distribution of Early Bronze Age metal artefacts in Estonia. a sickle, b axe, c spearhead, d Late Bronze Age axe from Põhjaka. 1 Eesnurga, 2, 6 Muhu, 3 Käesla, 4 Kaarma, 5 Tahula, 7 Järveküla, 8 Lelle, 9 Aseri, 10 Raidsaare (Taganurga), 11 Mõisamaa, 12 Tõstamaa, 13 Karksi, 14 Asumaa, 15 Valgjärve, 16 Põhjaka, 17 Kivisaare.

Joon 5. Vanema pronksiaja metallesemete levik Eestis. a sirp, b kirves, c odaots, d noorema pronksiaja kirves Põhjakalt.

Early Bronze Age found so far in Estonia. All bronze axes in question have been imported from (southern) Scandinavia, whereas the spearhead and the sickle originate from the eastern- and south-easternmost cultural regions.

It should also be noticed that the Kolga-Jaani group of drumlins is rather significant as for the artefacts of the Early Bronze Age found there. On Raidsaare drumlin in the village of Tagaküla, ca $8 \mathrm{~km}$ north of Eesnurga village, there was a flanged axe found in 1909 (Šturms 1935, fig. 1: 3). The find spot was located ca $50 \mathrm{~cm}$ deep in the layer of clay covering the bank of Navesti River, which is flooded in springs (Anni 1921, 36). One more find - the bronze sickle (see Šturms 1935, fig. 1: 6) - was discovered during the archaeological excavations of a multiperiod settlement site and cemetery at Kivisaare drumlin in the village of Meleski (Indreko 1935, 12). As this area is also remarkable by the density of earlier, i.e. Neolithic finds (Jaanits et al. 1982, pl. III-V) and the scarcity of later, Iron Age sites, these artefacts represent the last long-distance exchange connections of this ancient settlement centre. 


\section{Acknowledgement}

The authors are grateful to Kristel Külljastinen for preparing all illustrations.

\section{References}

Aner, E. 1962. Die frühen Tüllenbeile des nordischen Kreises. - Acta Archaeologica, XXXIII, 165-219.

Anni, A. 1921. Kolga-Jaani. (Manuscript in the archives of Institute of History.) Tallinn.

Baudou, E. 1960. Die regionale und chronologische Einteilung der jüngeren Bronzezeit im nordischen Kreis. (Acta Universitatis Stockholmiensis. Studies in North-European Archaeology, 1.) Stockholm.

Indreko, R. 1935. Viljandimaa muinasaeg. - Viljandimaa. Äratrükk. (Eesti, VI.) Tartu, 1-60.

Jaanits, L., Laul, S., Lõugas, V. \& Tõnisson, E. 1982. Eesti esiajalugu. Tallinn.

Montelius, O. 1917/1991. Minnen från vår forntid. Nytryck. Stockholm.

Moora, H. 1938. Neue Funde der Bronze- und frühen Eisenzeit aus Estland. - ÕES Ar., 1937, I, 365-380.

Oldeberg, A. 1974. Die ältere Metallzeit in Schweden, I. Stockholm.

Oldeberg, A. 1976. Die ältere Metallzeit in Schweden, II. Stockholm.

Šturms, E. 1935. Die Kulturbeziehungen Estlands in der Bronze- und frühen Eisenzeit. - ÕES Ar., 1932, 245-277.

Šturms, E. 1936. Die ältere Bronzezeit im Ostbaltikum. (Vorgeschichtliche Forschungen, 10.) Berlin; Leipzig.

\section{Valter Lang, Aivar Kriiska ja Arvi Haak \\ UUS VANEMA PRONKSIAJA PUTKKIRVES}

\section{Resümee}

2006. aasta talvel köitis Viljandi Muuseumis tähelepanu pronksist putkkirves, mis seni ei ole teaduskäibesse jõudnud. Kirves leiti Kolga-Jaanist 1,5 km kauguselt Eesnurga külast Lääne talu maalt juba 1971. aastal põllu kultiveerimise käigus traktorist Heino Mölteri poolt ja anti Viljandi Muuseumile üle 1996. aastal. Lääne talu paiknes praegu terves ulatuses põllustatud umbes $1 \mathrm{~km}$ pikkusel voorel (joon 1). 2006. aasta aprillis tehtud inspektsioonikäigul koguti kirjeldatud voorelt küll üksikuid tulekivi- ja savinõukilde, kuid selgemat muistist ei ole võimalik seal siiski eristada.

Eesnurga kirves (joon 2) on $142 \mathrm{~mm}$ pikkune, lehelt $43 \mathrm{~mm}$ laiune ja $285,7 \mathrm{~g}$ raskune; putke läbimõõt on väljastpoolt $34 \mathrm{~mm}$ ja seest $25 \mathrm{~mm}$, sügavus on $91 \mathrm{~mm}$.

Kirve dateerimine ja kultuurilise kuuluvuse määramine on komplitseeritud. Esmapilgul meenutab see kirveid, mida E. Šturms eristas Littausdorfi tüübina. Need Ida-Preisimaal, Ida-Saksamaal ja Poolas esinevad kirved on aga üldiselt massiivsemad ja lühemad kui Eesnurga eksemplar. Üks niisugune on leitud ka 
Eesti alalt Suure-Jaani lähedalt Põhjakast (joon 3). Kaasleidude järgi on niisugused kirved dateeritud Skandinaavia pronksiaja IV perioodiga (1100-900 eKr). Littausdorfi tüübile analoogseid kirveid on teada ka Lõuna-Skandinaaviast. IV ja V perioodi kirveste pikkus aga ei ületa $8-9 \mathrm{~cm}$. Selgeid sarnaseid jooni on Eesnurga kirvel A. Oldebergi poolt Skandinaavias eristatava E-rühma kirvestega. Vähemalt mõned selle rühma kirved on Eesnurga eksemplariga isegi sarnaselt dekoreeritud. Kaasleidude järgi on vähemalt osa neist olnud kasutusel III ja IV perioodi üleminekuetapil.

Täpset vastet Eesnurga kirvele ei olegi võimalik praegu tuua, kusjuures peamine erijoon on just kirve sihvakus, mis sobib oluliselt enam II ja III perioodi kui hilisemate perioodide kirvestele. Selles mõttes on Eesnurga kirves sarnane PõhjaEestist Järvekülast leitud unikaalse putkkirvega (joon 4).

Kokkuvõtvalt võib Eesnurga kirve esialgselt dateerida Skandinaavia pronksiaja III perioodiga. Oletatavasti on see valmistatud Lõuna-Skandinaavias. Tegemist on varase pronksiaja 16. pronksesemega (neist kaks on fikseeritud vaid leiuteatena): 14 kirvest, 1 sirp ja 1 odaots (joon 5). Kõik kirved on imporditud Skandinaaviast, odaots pärineb aga ida ja sirp ilmselt kagu poolt. On tähelepanuväärne, et Kolga-Jaani voorestikust on teada juba kolm varase pronksiaja pronkseset: Lääne talust umbes $8 \mathrm{~km}$ kauguselt Taganurga külas paiknevalt Randsaare voorelt on leitud rantkirves ja umbes $11 \mathrm{~km}$ kauguselt Meleski külas paiknevalt Kivisaarelt sirp. 